\title{
ZBTB7B wt Allele
}

National Cancer Institute

\section{Source}

National Cancer Institute. ZBTB7B wt Allele. NCI Thesaurus. Code C150353.

Human ZBTB7B wild-type allele is located in the vicinity of $1 \mathrm{q} 21.3$ and is approximately $16 \mathrm{~kb}$ in length. This allele, which encodes zinc finger and BTB domain-containing protein $7 \mathrm{~B}$, is involved in the repression of type I collagen gene expression and the promotion of CD4-positive T-cell differentiation. 